T. BALUCHNEJADMOJARAD ${ }^{1}$ and M. ROGHANI ${ }^{2}$

\title{
INVOLVEMENT OF HIGH-CONDUCTANCE CALCIUM-DEPENDENT POTASSIUM CHANNELS IN SHORT-TERM PRESYNAPTIC PLASTICITY IN THE RAT DENTATE GYRUS
}

\author{
Received August 7, 2012.
}

We examined the involvement of high-conductance calcium-dependent potassium (BK) channels in short-term presynaptic plasticity in the rat dentate gyrus; a paired-pulse stimulation protocol was used for evaluation of this phenomenon. Paired-pulse responses were recorded from the dentate gyrus of rats while stimulating the medial part of the perforant path with different interpulse intervals (IPIs). Iberiotoxin (IbTX), a selective blocker of BK channels, at doses of 50 and $100 \mu \mathrm{g} / \mathrm{kg}$ was i.p. administered $30 \mathrm{~min}$ presurgery. The population spike (PS) amplitude ratio and field EPSP (fEPSP) amplitude and slope ratios were measured at IPIs 10, 20,30, and $50 \mathrm{msec}$ as indices of synaptic facilitation and/or depression. At IPIs of 10 and $20 \mathrm{msec}$, there was no significant increase in the PS amplitude ratio after IbTX. However, at longer IPIs (30 and $50 \mathrm{msec}$ ), there was a significant dose-dependent increase in this ratio $v s$ the vehicle group $(P<0.05$ and $P<0.01$, respectively). There was a slight decrease in the fEPSP amplitude ratio at short IPIs $(10,20$, and $30 \mathrm{msec})$ in rats pretreated with IbTX, while insignificant incrases in the fEPSP amplitude ratio were observed at longer IPIs (50 msec). With respect to the fEPSP slope ratio, IbTX dose-dependently and insignificantly increased it. In addition, longer IPIs did not provide significant changes in the fEPSP slope ratio. High-conductance calcium-dependent potassium channels in the rat dentate gyrus have a modulatory (inhibitory) and (apparently) regulatory role in short-term presynaptic plasticity at relatively long ISIs, and blocking of these channels leads to paired-pulse facilitation.

Keywords: high-conductance calcium-dependent potassium channels, iberiotoxin, shortterm plasticity, paired-pulse stimulation protocol, hippocampus.

\section{INTRODUCTION}

Potassium channels are known as the most diverse ion channels involved in the regulation of neuronal excitability [1]. These channels pass outward potassium currents, which lead to hyperpolarization of the cell membrane and in this way attenuate the effects of excitatory influences. Since potassium channels reduce the neuronal excitability, they are regarded as inhibitory [1]. Calcium-activated potassium channels form a large family of potassium channels that are found throughout the CNS and are activated following elevation of the level of cytosolic calcium, largely in

\footnotetext{
${ }^{1}$ Department of Physiology, School of Medicine, Tehran University of Medical Sciences, Tehran, Iran.

${ }^{2}$ Neurophysiology Research Center, Shahed University, Tehran, Iran. Correspondence should be addressed to T. Baluchnejadmojarad (e-mail: tmojarad@yahoo.com).
}

response to calcium influx through voltage-operated calcium channels open during action potentials (APs) [2]. The involvement of these channels has been reported in the pathogenesis of some neurological and mental disorders [2]. One kind of these channels known as large-conductance calcium- and voltage-dependent potassium channels (also called BKCa, MaxiK, or BK channels) is widely expressed throughout the nervous system of vertebrates [1]. These channels are activated in response to calcium influx during APs and are responsible for spike repolarization and fast after-hyperpolarization [3]. Due to this, they can regulate the cell excitability and contribute to AP repolarization and spiking frequency adaptation [4]. Immunohistochemical and radioligand binding studies have revealed the presence of BK channels in the membranes of neuronal somata, processes, and axon terminals in several brain structures, including the hippocampus where they are particularly abundant 
[2]. The hippocampus is a key structure for certain kinds of learning and memory phenomena $[5,6]$. Synaptic plasticity in the hippocampus is known to be the neural substrate of the mnemonic processes $[5,6]$.

As is known, there are several forms of synaptic plasticity, including short- and long-term types. Pairedpulse stimulation is a standard technique for evaluation of short-term synaptic plasticity, and its effects in the hippocampus and the mechanisms underlying these effects have been intensely investigated, in particular in rodents [7, 8]. Paired-pulse facilitation (PPF) and paired-pulse depression (PPD) appear in the dentate gyrus of rats in a manner dependent on the stimulation site, stimulus intensity, and interpulse intervals (IPIs) [9]. Although paired-pulse responses in the hippocampus have been well characterized in rodents as an index of short-term plasticity [9], and the role of voltage-gated calcium channels have been reported in this respect [10], there is no information on the involvement of BK channels in modulation of this kind of plasticity in the dentate gyrus. Therefore, our study was designed to evaluate whether iberiotoxin (IbTX, a highly specific inhibitor of these channels) can modulate short-term presynaptic plasticity in the rat dentate gyrus following stimulation of the medial perforant path with different IPIs.

\section{METHODS}

Thirty male Wistar rats (220-250 g) were used. The animals were housed in Plexiglas cages (3-4 rats in each cage) and kept at a temperature of $22 \pm 2^{\circ} \mathrm{C}$ with a 12/12 light/dark cycle. Food and water were provided ad libitum. All experimental procedures were conducted according to the Guide for the Care and Use of Laboratory Animals of NIH and those of the Tehran University of Medical Sciences (Tehran, Iran).

Rats were i.p. pretreated with iberiotoxin, IbTX (Sigma, USA, 50 or $100 \mu \mathrm{g} / \mathrm{kg}$ ), $30 \mathrm{~min}$ before surgery. Iberiotoxin was dissolved in normal saline. Then, the animals that have received IbTX or vehicle were prepared for electrophysiological experiments. They were anesthetized with $1.5 \mathrm{~g} / \mathrm{kg}$ of urethane (i.p.) and fixed in a stereotaxic device. Body temperature of the animals was maintained at $37^{\circ} \mathrm{C}$ using a homeothermic blanket system. Small holes were drilled in the skull at the positions of the stimulating and recording electrodes. A recording electrode was positioned in the granular cell layer of the dentate gyrus $(\mathrm{AP}=-3.8$, $\mathrm{L}=2.5, \mathrm{~V}=2.8$ to $3.2 \mathrm{~mm}$ from the skull surface with respect to the bregma) according to the coordinates by Paxinos and Watson. A stimulating electrode was positioned at the angular bundle of the medial perforant path (4.2-4.3 $\mathrm{mm}$ lateral to the lambda, depth $\approx$ $\approx 2.8 \mathrm{~mm}$ ). The electrodes were lowered very slowly in order to minimize tissue damage. Final positions of the electrodes were estimated by observing evoked responses. Correct implantation of the electrodes was also confirmed by histological assessment. Fieldpotential recordings were obtained from the dentate gyrus following stimulation of the medial perforant path. Bipolar stimulating electrodes were made from Teflon-coated stainless steel (AM Systems, USA) with bare tips (diameter $0.125 \mathrm{~mm}$ ). Stimuli were generated using a constant-current isolated stimulator unit (NPI, Germany). Glass capillary recording electrodes (WPI Instruments, USA) had the resistance of 6-10 $\mathrm{M} \Omega$. Extracellular evoked potentials were preamplified (using an appropriate headstage from NPI, Germany), amplified $(\times 1000)$, filtered $(100 \mathrm{~Hz}$ to $5 \mathrm{kHz}$ bandpass $)$, digitized at $10^{4} \mathrm{sec}^{-1}$, and recorded with a differential extracellular amplifier (NPI, Germany). Data were analyzed using customized software.

Current-Response Relationship. Single stimuli (100-800 $\mathrm{AA}$, pulse width $50 \mu \mathrm{sec})$ were applied to the medial perforant path. Each current intensity was tested in a randomized order at least three times with $10-\mathrm{sec}$ interstimulation intervals. Evoked responses were recorded and analyzed online. The characteristic field response in the dentate granule cells to perforant path stimulation consisted of a positive fEPSP with a superimposed negative-going population spike (PS). The fEPSP slope ( 25 to $75 \%$ of the initial rising phase) and PS amplitude were measured for each response. In this respect, the PS amplitude was measured as the voltage difference between the peak of the first positive wave and the peak of the first negative deflection.

Paired-Pulse Protocol. Pairs of identical stimuli were delivered to the medial perforant path and initiated four consecutive evoked responses to paired pulses at 10-, 20-, 30-, and 50-msec-long interstinmulus intervals. The stimulus intensity (typically $800 \mu \mathrm{A}$, $50 \mu \mathrm{sec}$ ) was chosen such that the first evoked PS was maximal. The PS amplitude ratio (second PS amplitude/first PS amplitude qualified as paired-pulse index, PPI) was measured at different IPIs. A negative value indicated paired-pulse inhibition (PPD), whereas a positive value was indicative of PPF. The same measurement was also made for fEPSPs. In addition, the fEPSP slope ratio (second fEPSP slope/first fEPSP slope) was also measured. 
An average value was calculated from three successive trials with 15 -sec-long intervals between consequent trials. The interval at which $50 \%$ inhibition of the second PS would occur was calculated for each individual paired-pulse profile for determination of any synaptic changes of neurons of the dentate gyrus and its inhibitory internerouns and to evaluate shortterm plasticity.

Statistical Analysis. All data were expressed as means \pm s.e.m. and analyzed using one-way ANOVA and the Tukey post-test. $P$ values less than 0.05 were considered significant.

\section{RESULTS}

In our study, the effect of IbTX as a blocker of BK channels on short-term synaptic plasticity in the hippocampal dentate gyrus was evaluated. For this purpose, the PPI as an index of presynaptic facilitation or inhibition was determined at different IPIs intervals $(10,20,30$, and $50 \mathrm{msec})$. In this respect, as is shown in Fig. 1, at IPIs of 10 and $20 \mathrm{msec}$ there were some increased in the above index for PSs (their amplitude ratio but they did not reach the significance level). However, at longer IPIs (30 and $50 \mathrm{msec}$ ), the PPI for
A
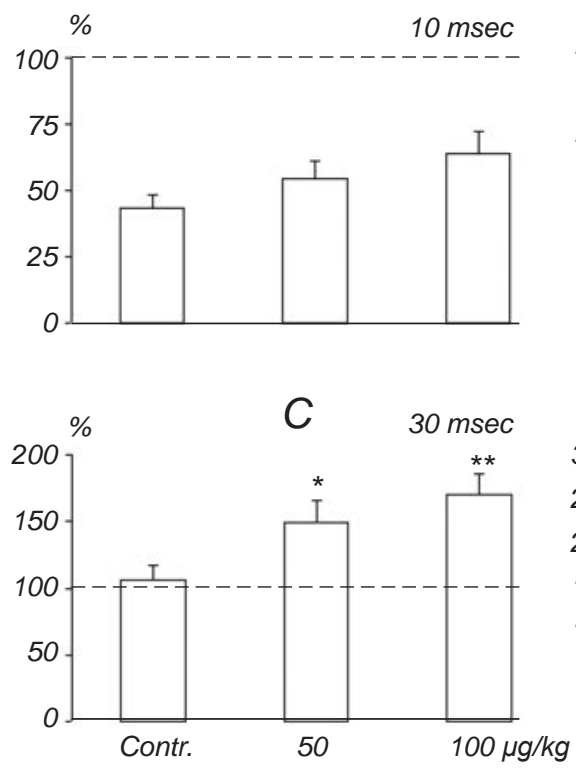

$B$

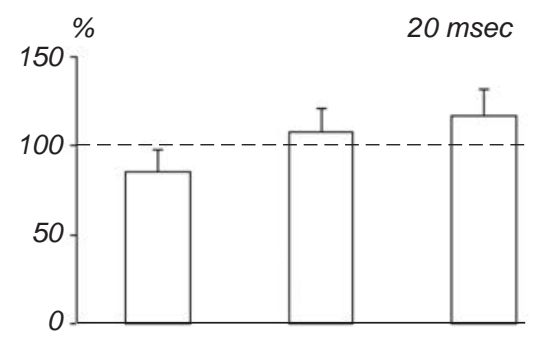

$D$

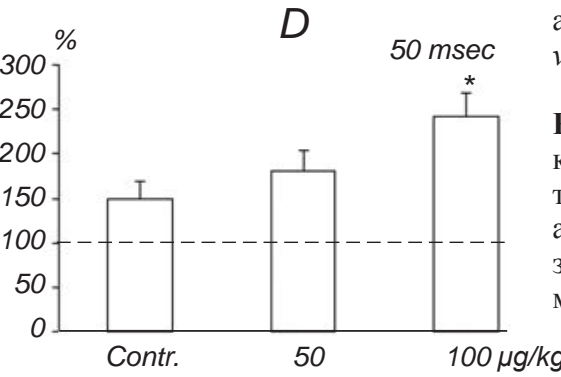

F i g. 1. Effects of the blocker of BK channels iberiotoxin at doses of 50 and $100 \mu \mathrm{g} / \mathrm{kg}$ (50 and 100 , respectively) on the ratio of population spike (PS) amplitudes (\%) in the dentate gyrus of the rat hippocampus at different interpulse intervals as shown at the right (A-D). ${ }^{*} P<0.05, * * P<0.01$ vs sham (Contr.).

P и с. 1. Впливи блокатора високопровідних кальційзалежних калієвих каналів іберіотоксину (50 та 100 мкг/кг) на відношення амплітуд (\%) популяційних піків у зубчастій звивині гіпокампа щурів при різних міжстимульних інтервалах $(A-D)$.
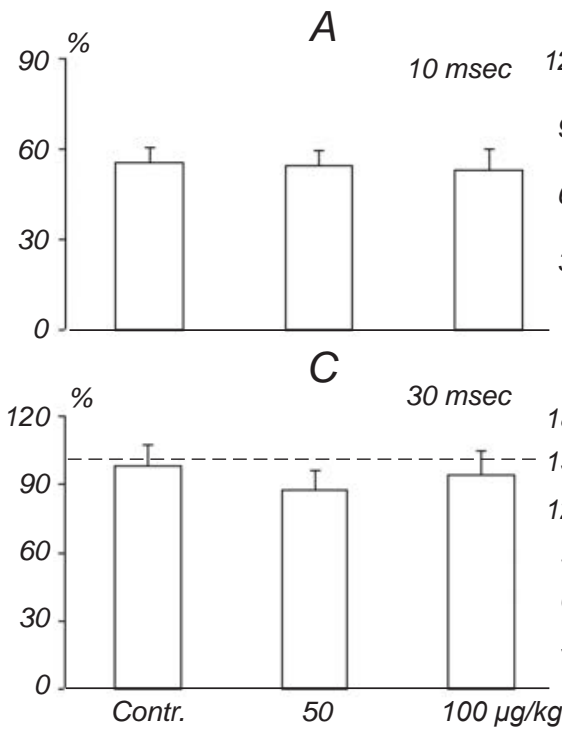
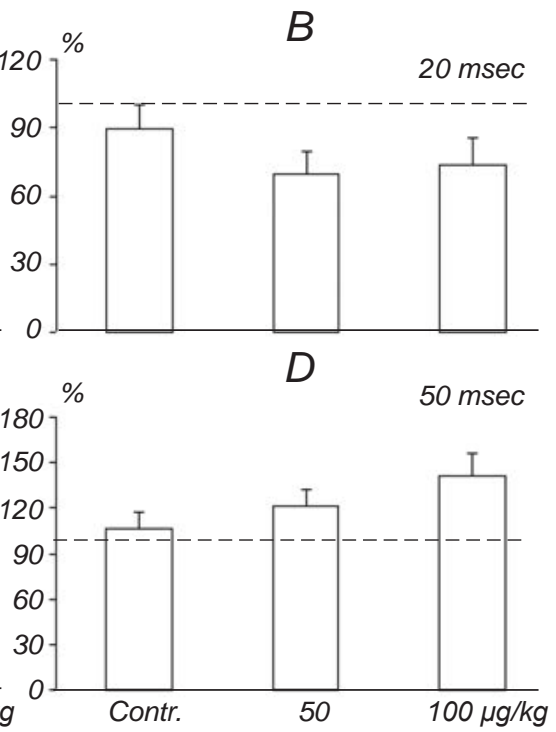

F i g. 2. Effects of iberiotoxin (IbTX) at doses of 50 and $100 \mu \mathrm{g} / \mathrm{kg}$ on the ratio of fEPSP amplitudes $(\%)$ in the dentate gyrus of the rat hippocampus at different interpulse intervals as shown at the right (A-D). Other designations are the same as in Fig. 1.

Р и с. 2. Впливи іберіотоксину (50 та 100 мкг/кг) на відношення амплітуд (\%) популяційних ЗПСП у зубчастій звивині гіпокампа щурів при різних міжстимульних інтервалах $(A-D)$. 

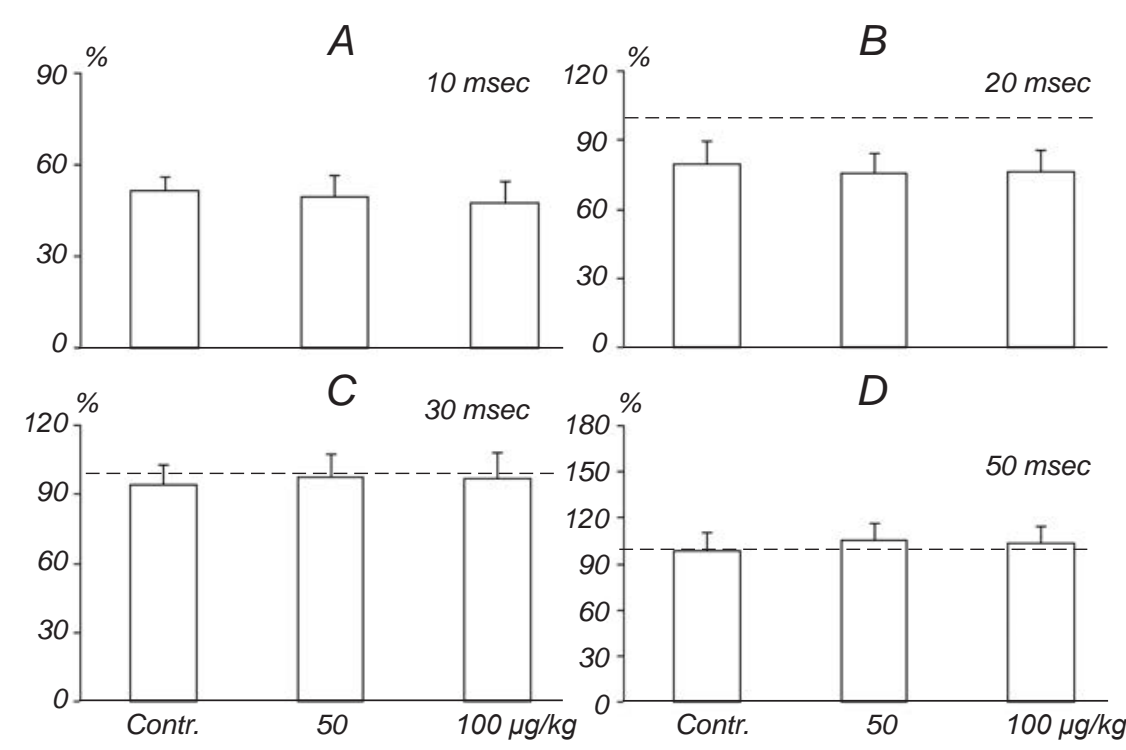

F i g. 3. Effects of iberiotoxin (IbTX) at doses of 50 and $100 \mu \mathrm{g} / \mathrm{kg}$ on the fEPSP slope ratio (\%) in the dentate gyrus of the rat hippocampus at different interpulse intervals as shown at the right (A-D). Other designations are the same as in Fig. 1 .

Р и с. 3. Впливи іберіотоксину (50 та 100 мкг/кг) на відношення швидкості наростання (\%) фокальних ЗПСП у зубчастій звивині гіпокампа щурів при різних міжстимульних інтервалах $(A-D)$.
PSs was significantly greater after IbTX pretreatment $(P<0.05$ and $P<0.01)$, and the observed responses followed a dose-response pattern. In other words, PPF was observed at IPIs of 30 and $50 \mathrm{msec}$ in rats pretreated with IbTX (at doses of 50 and $100 \mu \mathrm{g} / \mathrm{kg}$ ), as compared to the vehicle group.

In addition, as is shown in Fig. 2, the fEPSP amplitude ratio was also calculated as another index for presynaptic facilitation or depression. At relatively short IPIs $(10,20$, and $30 \mathrm{msec})$, slightly smaller fEPSP amplitude ratios were found in rats pretreated with IbTX. Thus, mild (insignificant) presynaptic depression was observed under the action of IbTX. In addition, at longer IPIs $(50 \mathrm{msec})$, there were clearly but insignificantly greater fEPSP amplitude ratios, indicating slight presynaptic facilitation.

Regarding the fEPSP slope ratio (Fig. 3), IbTX pre-

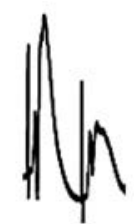

10
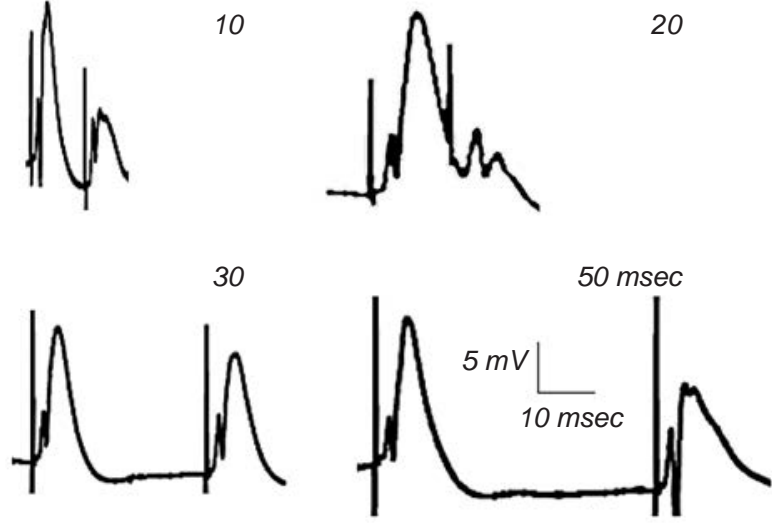

treatment somewhat increased it in a dose-dependent manner, but intergroup differences did not reach the significance level. In addition, an increase in the duration of IPIs did not cause marked changes in the fEPSP slope ratio. Some representative traces of paired-pulse evoked responses after IbTX administration at a dose of $100 \mu \mathrm{g} / \mathrm{kg}$ are demonstrated in Fig. 4.

\section{DISCUSSION}

Following IbTX, there was no significant increase in the PS amplitude ratio at IPIs equal to 10 or 20 msec. However, at longer IPIs (30 and $50 \mathrm{msec}$ ), we observed significantly greater PS amplitude ratios $v s$ the vehicle group, and this increase was dosedependent. Regarding the fEPSP amplitude ratio, there

F i g. 4. Representative traces of paired-pulse evoked responses in the dentate gyrus of the rat hippocampus following stimulation of the medial perforant path at different interpulse intervals after iberiotoxin administration at a dose of $100 \mu \mathrm{g} / \mathrm{kg}$.

P и c. 4. Приклади відповідей, відведених у зубчастій звивині гіпокампа щура при парній стимуляції (з різними міжстимульними інтервалами) медіального перфорантного шляху після ін'єкцій 100 мкг/кг іберіотоксину. 
were slight decreases in the fEPSP amplitude ratio in rats pretreated with IbTX at short IPIs $(10,20$, and $30 \mathrm{msec})$, while at longer IPIs $(50 \mathrm{msec})$, there was an insignificant increase in this index. With respect to the fEPSP slope ratio, IbTX dose-dependently but insignificantly increased it. In addition, increasing durations of IPIs did not cause a significant change in the fEPSP slope ratio.

The dentate gyrus receives its major input from the entorhinal cortex via the so-called perforant pathway. The respective contacts are localized primarily on the dendrite spines of granule cells, although a small number of perforant path fibers also form asymmetric synapses on the shafts of GABA-positive interneurons [11]. It seems that IbTX inhibits BK channels on glutamatergic terminals of this pathway at longer IPIs and, therefore, provides augmented glutamate release leading to short-term facilitation. In addition, it appears that GABA-ergic neurons have a relatively low density of such channels and, because of this, synaptic facilitation was observed in our study following IbTX treatment. In support of this hypothesis and according to the existing literature, BK channels can preferentially control glutamate release, whereas they appear to exert only a minor influence over GABA release [12]. Although the excitability of granular and pyramidal cells in the hippocampus is believed to be regulated by both feedback and feedforward GABA-mediated mechanisms [10], our results clearly suggest that the blockade of BK potassium channels may increase the total calcium signal in the terminals provoking the enhancement of glutamate release from medial perforant path terminals on cells of the dentate gyrus and, to a lesser degree, intensifying the release of GABA from terminals of GABA-ergic interneurons. Thus, the net effect would be PPF at longer IPIs, which was precisely observed in our study. In addition, according to previous reports, PPF is prominent in synapses with a low initial probability of transmitter release and is characterized by increase in the amount of a neurotransmitter released in response to the second stimulus [10]. Since the fEPSP2/fEPSP1 amplitudes and slope ratios did not significantly change in IbTX-pretreated rats, it is possible that projections of inhibitory interneurons terminate on the somata of cells of the dentate gyrus and, therefore, determine the input/output of the target cells. To conclude, our study showed that BK channels in the rat dentate gyrus have a modulatory (inhibitory) and an apparently regulatory role in short-term pre- synaptic plasticity at relatively long interstimulus intervals, and their blockade leads to PPF.

Acknowledgments. This research was funded and supported by the TUMS grant No. 851 (Tehran University of Medical Sciences).

\section{T. Балухнеджадмоджарад ${ }^{1}$, М. Рогані ${ }^{2}$}

\section{ЗАЛУЧЕННЯ ВИСОКОПРОВІДНИХ}

КАЛЬЦІЙЗАЛЕЖНИХ КАЛІЄВИХ КАНАЛІВ У КОРОТКОЧАСНУ ПРЕСИНАПТИЧНУ ПЛАСТИЧНІСТЬ У ЗУБЧАСТІЙ ЗВИВИНІ ЩУРА

\author{
${ }^{1}$ Медичний факультет Тегеранського університета медич- \\ них наук (Іран). \\ ${ }^{2}$ Нейрофізіологічний дослідницький центр, Університет \\ Шахед, Тегеран (Іран). \\ P е 3 ю м е
}

Ми досліджували залучення викосопровідних кальційзалежних калієвих каналів (ВК-каналів) у короткочасну пресинаптичну пластичність у зубчастій звивині щурів; для оцінки цього феномену застосовували протокол парної стимуляції. Відповіді у зубчастій звивині реєстрували після подразнення медіальної частини перфорантного шляху парними стимулами, що подавалися 3 різними міжстимульними інтервалами (MCI). Іберіотоксин (IbTX) - селективний блокатор ВК-каналів - ін'єкували внутрішньоочеревинно в дозах 50 та 100 мкг/кг за 30 хв до початку відведення. Відношення амплітуд популяційних піків (ПП), амплітуд популяційних викликаних постсинаптичних потенціалів (пВПСП) і значень швидкості наростання останніх вимірювали при MCI, що дорівнювали 10, 20, 30 та 50 мс; ці величини розглядали як індекси синаптичного полегшення або депресії. Після введення IbTX у випадках, коли MCI становили 10 та 20 мс, ми не спостерігали значного зростання відношення амплітуд ПП. Проте у випадках, коли використовували триваліші MCI (30 та 50 мс), цей індекс демонстрував значне дозозалежне збільшення (порівняно 3 його значеннями в групі щурів, які отримували розчинник. Щодо відношення амплітуд пВПСП слід зазначити, що ми спостерігали слабке зменшення даного індексу у тварин, котрим попередньо ін'єкували IbTX, у випадках використання коротких MCI $(10,20$ та $30 \mathrm{mc})$ і незначне збільшення такого відношення при триваліших MCI (50 мс). Що ж до швидкості наростання пВПСП, то IbTX дозозалежно та статистично невірогідно збільшував вказаний індекс. Крім того, збільшення тривалості МCI не спричиняло значних змін швидкості наростання цих потенціалів. У межах зубчастої звивини щурів ВК-канали відіграють модуляторну (гальмівну) та, безсумнівно, регуляторну роль у короткотривалій пресинаптичній пластичності при відносно тривалих МСI; блокування даних каналів призводить до полегшення в умовах парної стимуляції. 


\section{REFERENCES}

1. B. Hille, Ion Channels of Excitable Membranes, Sinauer Associates, Inc., Sunderland, Mass. (2001).

2. S. G. Wanner, R. O. Koch, A. Koschak, et al., "Highconductance calcium-activated potassium channels in rat brain: pharmacology, distribution, and subunit composition," Biochemistry, 38, No. 17, 5392-5400 (1999).

3. M. D. Womack, C. Hoang, and K. Khodakhah, "Large conductance calcium-activated potassium channels affect both spontaneous firing and intracellular calcium concentration in cerebellar Purkinje neurons," Neuroscience, 162, No. 4, 9891000 (2009).

4. N. Gu, K. Vervaeke, and J. F. Storm, "BK potassium channels facilitate high-frequency firing and cause early spike frequency adaptation in rat $C A 1$ hippocampal pyramidal cells, " $J$. Physiol., 580, Part 3, 859-882 (2007).

5. H. Eichenbaum, "Hippocampus: cognitive processes and neural representations that underlie declarative memory," Neuron, 44, No. 1, 109-120 (2004).

6. T. V. Bliss and G. L. Collingridge, "A synaptic model of memory: long-term potentiation in the hippocampus," Nature, 361, No. 6407, 31-39 (1993).
7. R. S. Zucker and W. G. Regehr, "Short-term synaptic plasticity," Annu. Rev. Physiol., 64, 355-405 (2002).

8. R. Tamura, H. Nishida, S. Eifuku, et al., " Short-term synaptic plasticity in the dentate gyrus of monkeys," PLoS One, 6, No. 5, e20006 (2011).

9. J. D. Bronzino, J. H. Blaise, and P. J. Morgane, "The pairedpulse index: a measure of hippocampal dentate granule cell modulation," Ann. Biomed. Eng., 25, No. 5, 870-873 (1997).

10. R. Lashgari, F. Motamedi, S. M. Noorbakhsh, et al., “Assessing the long-term role of L-type voltage dependent calcium channel blocker verapamil on short-term presynaptic plasticity at dentate gyrus of hippocampus," Neurosci. Lett., 415, No. 2 , 174-178 (2007).

11. D. G. Amaral, H. E. Scharfman, and P. Lavenex, "The dentate gyrus: fundamental neuroanatomical organization (dentate gyrus for dummies)," Prog. Brain Res., 163, 3-22 (2007).

12. M. Martire, V. Barrese, M. D'Amico, et al., "Pre-synaptic BK channels selectively control glutamate versus GABA release from cortical and hippocampal nerve terminals," $J$. Neurochem., 115, No. 2, 411-422 (2010). 